\section{Neurological Decompression Sickness Treated without Recompression}

\author{
R. C. SAUMAREZ, J. F. BOLT, R. J. GREGORY
}

British Medical fournal, 1973, 1, 151-152

The conventional treatment of type II decompression sickness is immediate recompression, which shrinks any intravascular gas bubble and causes it to go back into solution. There is now evidence which requires reappraisal of the concept that a simple intravascular gas bubble is the major pathological factor in type II decompression sickness. After fatal decompression multiple systemic and pulmonary fat emboli have been found in dogs and in man (Clay, 1963). The composition of these fat emboli indicate that they are of metabolic origin. An absolute thrombocytopenia and a hyperliproteinaemia have been described in severe decompression sickness (Pauley and Cockett, 1970). Wells at al. (1971) found that in rapidly decompressed dogs erythrocyte and platelet aggregations occur, which do not appear to nucleate on gas bubbles. In type II decompression sickness the lesion would therefore appear to be a stable lipid/platelet embolus, and so rational medical therapy should be aimed at improving perfusion distal to the embolus and its destruction.

\section{Case Report}

A 34-year-old man who was a professional diver had suffered three previous decompression accidents, one of which had left him with signs of posterior column damage. In August 1971 he performed three consecutive dives of 15 minutes each to depths of between 150 and $180 \mathrm{ft}$ ( 46 and $55 \mathrm{~m}$ ) followed by a decompression schedule of 15 minutes rather than the standard 127 minutes. On leaving the water he felt a severe pain in his right shoulder and a sensation of weakness in his right arm. After returning to shore his symptoms were still present and later at home he developed vertigo and unsteadiness in walking. He was persuaded to enter hospital 16 hours later during which time he had drunk $1 \frac{1}{2}$ bottles of whisky. On admission the patient complained of severe pain in his right shoulder and of an inability to move his right arm. $\mathrm{He}$ also complained of vertigo, which had begun before he started drinking. On examination he was drunk, querulous, but orientated. There were rhonchi throughout the chest but no other abnormalities of the cardiovascular or respiratory systems were noted.

In the central nervous system there was a right homonomous visual field defect and a deficit of conjugate gaze to the right. $\mathrm{He}$ had nystagmus with the fast component to the right and could not raise his right shoulder. His tendon reflexes were brisk on the left but were absent or very much reduced on the right. Both plantar responses were flexor and he was unable to perform the fingernose and heel-shin tests with his eyes open or shut. There was a

Guy's Ho'spital, London S.E.1

R. C. SAUMAREZ, B.Sc., Medical Student

Princess Elizabeth Hospital, Guernsey

J. F. BOLT, M.B., D.A., Anaesthetist and General Practitioner R. J. GREGORY, M.R.C.P., D.A., Physician total sensory loss in his right arm and hand. A diagnosis was made of mixed type I and type II decompression sickness.

Investigations on admission were: haemoglobin, $16 \cdot 1 \mathrm{~g} / 100 \mathrm{ml}$ packed cell volume, $48 \% \mathrm{~mm}^{3}$; platelets, $100,000 / 1$; total plasma lipids, $1,030 \mathrm{mg} / 100 \mathrm{ml}$; plasma lipoproteins, $230 \mathrm{mg} / 100 \mathrm{ml}$; arterial pH, 7.32; $\mathrm{Po}_{2}, 75 \mathrm{~mm} \mathrm{Hg} ; \mathrm{PCO}_{2} 51 \mathrm{mg} \mathrm{Hg} ; \mathrm{HCO}_{3}, 22 \cdot 0$ $\mathrm{mEq} / 1$.

The patient was treated initially with pentazocine $100 \mathrm{mg}$ intramuscularly and $100 \%$ oxygen; $500 \mathrm{ml}$ dextran 40 in saline were infused in 15 minutes; heparin 12,500 IU and frusemide $40 \mathrm{mg}$ was given intravenously. Then he was given a second drip of $500 \mathrm{ml}$ mannitol followed by $500 \mathrm{ml} 20 \%$ fructose, which sobered him, and $500 \mathrm{ml} 8.4 \%$ sodium bicarbonate solution. His bronchoconstriction and arterial hypoxaemia persisted, and he was given intravenous aminophylline $500 \mathrm{mg}$ followed by $250 \mathrm{mg}$ four-hourly. After this there was a steady rise in arterial $\mathrm{Po}_{2}$ and a fall in $\mathrm{PCO}_{2}$ (chart). The next day his electrocardiogram showed evidence of

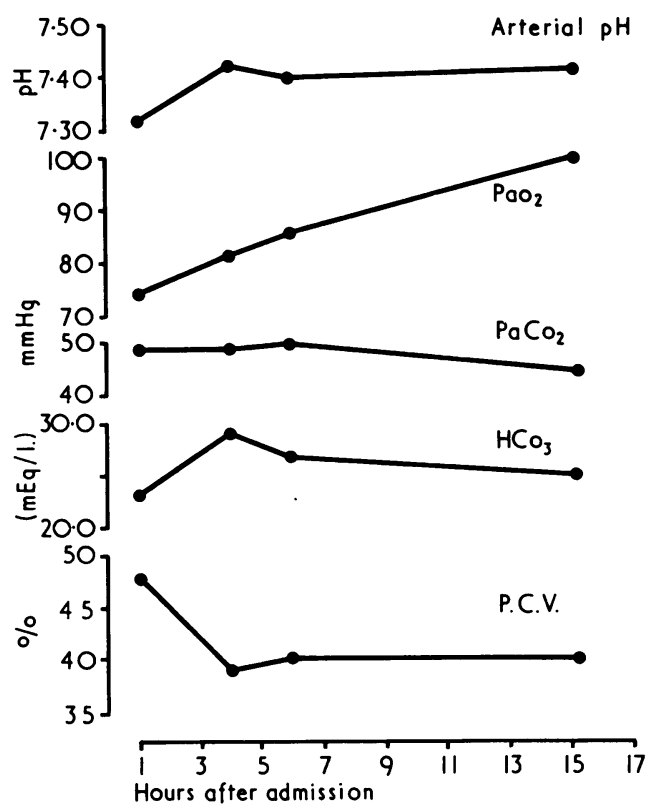

Various arterial levels and packed cell volume in patient with decompression sickness.

right ventricular strain but his chest $x$-ray appearances were normal. After two hours all neurological signs had regressed except for slight right-sided nystagmus. He became very agitated and was sedated with chlorpromazine. Subsequently he was treated with $500 \mathrm{ml}$ dextran 40 in dextrose solution eight-hourly, heparin 12,500 units four-hourly, and chlorpromazine $100 \mathrm{mg}$ six-hourly for 48 hours. For the first 28 hours he breathed $100 \%$ oxygen, followed by $28 \%$ oxygen for the remaining 20 hours. He was discharged home four days later; a slight right-sided nystagmus remained the only abnormal neurological sign, apart from the sensory loss in his feet caused by a previous diving accident.

\section{Comment}

The aim of medical therapy in type II decompression sickness is to improve the tissue oxygenation by reversing the changes in the microvasculature induced by bubble formation. Dextran 40 has been shown to be of benefit in embolic strokes 
by improving tissue perfusion and causing activated platelets to return to their normal morphology (Gilroy et al., 1969). Haemoconcentration, which may be accompanied by cerebral oedema, is a feature of severe decompression sickness, and plasma expansion alone has been used successfully in two cases (Brunner et al., 1964). In the present case the initial packed cell volume was $48 \%$, suggesting haemoconcentration and cerebral oedema, and thus mannitol was given.

The use of heparin in fat embolism has been described (Cobb et al., 1968), its actions on lipoprotein lipase and platelets probably being the most important. Heparin has also been used successfully as adjuvent therapy to recompression in five cases (Barthelemy, 1963). Also rapidly decompressed dogs when treated with heparin $(2 \mathrm{mg} / \mathrm{kg}$ ) have shown $100 \%$ survival, while the controls died (Pauley and Cockett, 1970). In the present case $100 \%$ oxygen was given to counteract the patient's arterial hypoxaemia, which may have been caused by microemboli in the pulmonary circulation, and to increase the capillary-alveolar diffusion gradient for nitrogen elimination. At present, recompression is the only generally accepted treatment for type II decompression sickness. The rationale for medical treatment of such cases, however, is supported by the successful management of this patient.

\section{References}

Barthelemy, L. (1963). National Academy of Science Publications, 46, 1181 .

Brunner, F. P., Frick, P. G., and Buhmann, A. A. (1964). Lancet, 1, 1071.

Clay, J. R. (1963). Aerospace Medicine, 34, 1107.

Cobb, C. A., jun., LeQuire, U. S., Gray, M. E., and Hillman, W. J. 1968. Surgical Forum, 19,751.

Gilroy, J. Barnhart, M. I. and Meyer, J. S. (1969). Fournal of the American Medical Association, 210, 293.

Pauley, S. M., and Cockett, A. K. T., (1970). fournal of Aerospace Medicine, 41, su.

Wells, C. H., Bond, T. P., Guest, M. M., and Barnhart, C. C. (1971) Microvascular Research, 3, 162.

\section{Hypopituitarism after Extracranial Irradiation: Evidence for Hypothalamic Origin}

\author{
R. G. LARKINS, F. I. R. MARTIN
}

British Medical fournal, 1973, 1, 152-153

In contrast with the known radioresistance of the normal pituitary gland (Kelly et al., 1951) the hypothalamus appears to be radiosensitive (Arnold et al., 1954). To our knowledge, however, there has been only one report of hypopituitarism occurring after irradiation for extracranial neoplasia (Tan and Kunaratnam, 1966). We report two such cases after external irradiation of carcinomas of the nasopharynx and maxillary antrum. Case 1 was previously mentioned in discussion by Bradley (1965).

\section{Case 1}

A man aged 45 presented in 1954 with multiple cranial nerve lesions. After extensive investigation, including exploration of the posterior fossa with negative results, the diagnosis of a small anaplastic carcinoma of the nasopharynx, confirmed by biopsy, was made. Deep $x$-ray therapy was administered, a $250-\mathrm{kV}$ machine being used and a 3,000-r tissue dose given over 25 days. Four oblique fields, which included the base of the skull in the region of the sella turcica, were used to deliver the radiation from both sides of the skull. An identical course was repeated five months later because of residual facial nerve weakness.

In 1962, although there was no evidence of recurrence, typical clinical features of hypopituitarism were present, including tiredness, intolerance of cold, impotence, loss of body hair, pallor, and testicular atrophy. Radiographs of the skull were normal. The clinical diagnosis was confirmed by the following investigations: serum protein-bound iodine $1.6 \mu \mathrm{g} / 100 \mathrm{ml}$, urinary gonadotrophins

Department of Endocrinology, Royal Melbourne Hospital, Victoria, Australia

R. G. LARKINS, M.D., M.R.A.C.P., Assistant Endocrinologist F. I. R. MARTIN, M.D., F.R.A.C.P., Endocrinologist
$<5.0$ mouse units $/ 24 \mathrm{hr}$, urinary 17-hydroxysteroids $2.0 \mathrm{mg} / 24 \mathrm{hr}$ before and $3.2 \mathrm{mg} / 24 \mathrm{hr}$ after metyrapone, and acute water load excretion increased from $17 \%$ to $81 \%$ after prednisolone $10 \mathrm{mg}$. Clinical improvement followed treatment with cortisone, testosterone, and thyroxine, but he subsequently developed right-sided conductive deafness and epilepsy, which were attributed to radiation damage. In 1968, after a haemoptysis, a chest radiograph showed a carcinoma of the lung, and evidence of metastases in bone and liver rapidly appeared. Death occurred in February 1970.

Necropsy showed no evidence of recurrence of the nasopharyngeal tumour, but the presence of a bronchial carcinoma was confirmed, with metastases in the liver, lung, and spine. Macroscopically, the brain and the pituitary were normal. Unfortunately, a more detailed examination was not performed.

\section{Case 2}

A man aged 39 presented in 1964 with a carcinoma of the left maxillary sinus involving the floor of the orbit. This was treated by irradiation; a megavoltage machine was used to deliver $6,500 \mathrm{r}$ in 20 increments over 32 days. Subsequently the left eye was enucleated and he developed bilateral conductive deafness attributable to radiation damage.

In 1971, when admitted for exploration of suspected tumour recurrence or osteomyelitis of the frontal bone, he gave a history suggestive of hypopituitarism and examination showed pale skin, absent body hair, and testicular atrophy. Urinary gonadotrophins were $<5.0$ mouse units $/ 24 \mathrm{hrs}$, and serum protein-bound iodine $2.9 \mu \mathrm{g} / 100 \mathrm{ml}$. An $x$-ray film of the pituitary fossa was normal.

Investigation of Hypothalamic Pituitary Function

\begin{tabular}{|c|c|c|c|c|c|c|c|c|c|}
\hline \multirow{2}{*}{ Stimulus } & \multirow{2}{*}{$\begin{array}{c}\text { Plasma } \\
\text { Concen- } \\
\text { tration }\end{array}$} & \multicolumn{8}{|c|}{ Time in Minutes } \\
\hline & & 0 & 5 & 10 & 20 & 30 & 60 & 90 & 120 \\
\hline $\begin{array}{l}\text { Insulin } \\
(0 \cdot 1 \\
\text { IU/kg } \\
\text { intra- } \\
\text { venously) }\end{array}$ & $\left\{\begin{array}{l}\text { Sugar } \\
\text { (mg/100ml) } \\
\text { Cortisol } \\
\text { ( } \mathrm{gg} / 100 \mathrm{ml}) \\
\text { Growth } \\
\text { hormone } \\
\text { (ng/ml) }\end{array}\right.$ & $\begin{array}{l}56 \\
2 \cdot 4 \\
3 \cdot 6\end{array}$ & & & & $\begin{array}{l}17 \\
2.8 \\
1.9\end{array}$ & $\begin{array}{l}42 \\
3.6\end{array}$ & $\begin{array}{l}45 \\
3 \cdot 2 \\
2 \cdot 6\end{array}$ & - \\
\hline $\begin{array}{l}\text { Vaso- } \\
\text { pressin } \\
\text { (5 IU } \\
\text { intramus- } \\
\text { cularly) }\end{array}$ & $\begin{array}{l}\text { Cortisol } \\
\text { ( } \mu \mathrm{g} / 100 \mathrm{ml}) \\
\text { Growth } \\
\text { hormone } \\
(\mathrm{ng} / \mathrm{ml})\end{array}$ & $\begin{array}{l}5.9 \\
1.5\end{array}$ & & & & & $20 \cdot 6$ & & - \\
\hline $\begin{array}{l}\text { Thyro- } \\
\text { trophin- } \\
\text { releasing } \\
\text { hormone } \\
\text { (200 } \mathrm{gg} \\
\text { intra- } \\
\text { venously) }\end{array}$ & $\begin{array}{l}\text { Thyroid- } \\
\text { stimulating } \\
\text { hormone } \\
(\mu \mathrm{U} / \mathrm{ml})\end{array}$ & $2 \cdot 8$ & 3.5 & $4 \cdot 6$ & $7 \cdot 4$ & 9.5 & $14 \cdot 4$ & & $14 \cdot 8$ \\
\hline
\end{tabular}

